\title{
AKTIVITAS ANTIOKSIDAN TUMBUHAN SURUHAN (Peperomia pellucida [L.] Kunth)
}

\author{
Erwin Sitorus $^{1)}$, Lidya Irma Momuat ${ }^{1)}$, Dewa Gede Katja ${ }^{1)}$ \\ ${ }^{1)}$ Program Studi Kimia FMIPA Universitgas Sam Ratulangi \\ Jl. Kampus Unsrat, Manado 95115 \\ erwin_chemist@yahoo.com; Imomuat@yahoo.com; dewakatja@yahoo.com
}

\begin{abstract}
ABSTRAK
Penelitian ini bertujuan untuk mempelajari aktivitasantioksidan tumbuhan suruhan, dengan mengukur total antioksidan tumbuhan pada keadaan segar dan kering, serta tanpa dan dengan pemanasan. Total antioksidan diukurmenggunakan metode FRAP (Ferric Reducing Antioxidant Power) dan absorbansinya dibaca padaspektrofotometer UV-Vis dengan panjang gelombang 593 nm. Hasil penelitian menunjukkan bahwa total antioksidan ekstrak suruhan kering sebesar 3,25 $\mathrm{mmol} / 100 \mathrm{~g}$ dan ekstrak suruhan segar $0,21 \mathrm{mmol} / 100 \mathrm{~g}$. Total antioksidan tertinggi pada ekstrak suruhan kering dengan pemanasan $4,05 \mathrm{mmol} / 100 \mathrm{~g}$, diikuti oleh ekstrak suruhan kering tanpa pemanasan 2,44 mmol/100g, ekstrak suruhan segar dengan pemanasan $0,35 \mathrm{mmol} / 100 \mathrm{~g}$ dan ekstrak suruhan segar tanpa pemanasan $0,08 \mathrm{mmol} / 100 \mathrm{~g}$. Penelitian ini menyimpulkan bahwa kandungan total antioksidan ekstrak suruhan kering lebih tinggi daripada ekstrak suruhan segar, dan pemanasan pada suhu $100^{\circ} \mathrm{C}$ selama 15 menit meningkatkan total antioksidan dalam ekstrak tumbuhan suruhan.
\end{abstract}

Kata kunci: Peperomia pellucida, total antioksidan, metode FRAP

\section{ANTIOXIDANT ACTIVITY OF Peperomia pellucida [L.] Kunth}

\begin{abstract}
This research aims to study the antioxidant activity ofPeperomia pellucida, by measuring the total antioxidant of the fresh and driedplant extract, withorwithoutheated.The total antioxidantwas measured using the method of Ferric ReducingAntioxidantPower (FRAP) and the absorbance read at 593 of UV-Vis spectrophotometer. The results showed that the total antioxidant of Peperomia $p$. dried extract was $3.25 \mathrm{mmol} / 100 \mathrm{~g}$ and the fresh extract was $\mathrm{mmol} / 100 \mathrm{~g} 0.21$. Dried Peperomia p.extract with heatedhasthe highest total antioxidant $(4,05 \mathrm{mmol} / 100 \mathrm{~g})$, followedby thedry extractwithout heated $(2.44 \mathrm{mmol} / 100 \mathrm{~g})$, the fresh extract with heated $(0.35 \mathrm{mmol} / 100 \mathrm{~g})$ and without heated $(0.08 \mathrm{mmol} / 100 \mathrm{~g})$. This study concluded that the total antioxidant of dried extract of Peperomia p. was higher than the fresh extract, and heating at $100{ }^{\circ} \mathrm{C}$ for $15 \mathrm{~min}$ increase total antioxidant of the plant extract.
\end{abstract}

Keywords: Peperomia pellucida, total antioxidant, FRAP method

\section{PENDAHULUAN}

Timbulnya beberapa penyakit, seperti penyakit jantung koroner, diyakini berhubungan erat dengan proses oksidasi dalam tubuh. Penyakit jantung koroner, yang merupakan salah satu penyebab utama kematian masyarakat dunia dewasa ini, dapat disebabkan oleh aterosklerosis atau penyempitan dinding pembuluh darah. Awal terjadinya aterosklerosis erat kaitannya dengan oksidasi lipid, terutama lipid dalam partikel lipoprotein berdensitas rendah (low density lipoprotein, LDL) (Steinberg, 1997).

Radikal bebas memainkan peranan penting dalam oksidasi lipida.Radikal bebas adalah atom atau molekul yang sangat reaktif karena mengandung elektron yang tidak berpasangan.Radikal bebas yang menyerang struktur tubuh mengakibatkan munculnya beragam penyakit (Dalimartha dan Soedibyo, 1999). 
Untuk menetralisir kerja radikal bebas dibutuhkan antioksidan. Antioksidan merupakan senyawa yang dapat mencegah reaksi oksidasi, dengan cara memberikan elektronnya kepada molekul radikal bebas sehingga dapat menghentikan reaksi berantai yang disebabkan oleh radikal bebas (Kumalaningsih, 2006).Antioksidan secara alami terkandung dalam tumbuhan. Total antioksidan yang terdapat pada tumbuhtumbuhan sangat beragam. Beberapa senyawa antioksidan yang berupa metabolit sekunder telah berhasil diisolasi dari berbagai jenis tumbuhan dan telah dimanfaatkan sebagai bahan baku obat-obatan (Subroto, 2006). Halvorsen et al. (2002) mengemukakan bahwa penggunaan antioksidan senyawa tunggal kurang memberikan manfaat dalam menghambat kerja radikal bebas dibandingkan dengan total senyawa antioksidan yang terdapat dalamsuatu bahan makanan.

Tumbuhan suruhan (Peperomia pellucida[L.]Kunth) secara tradisional telah dimanfaatkan dalam mengobati beberapa penyakit, seperti abses, bisul, jerawat, radang kulit, penyakit ginjal, dan sakit perut (Hariana, 2006). Masyarakat di beberapa daerah di Sulawesi Utara telah juga memanfaatkan tanaman ini untuk penurun kolesterol darah. Tarigan et al. (2012) melaporkan bahwa ekstrak etanol herba suruhan mempunyai efek antihiperurisemia terhadap mencit. Potensi tumbuhan suruhan sebagai senyawa antikanker, antimikroba dan antioksidan telah dilaporkan oleh Wei et al. (2011).Kemampuan tanaman suruhan sebagai tanaman obat diduga berkaitan erat dengan kandungan antioksidan pada tanaman tersebut.

Sejauh ini belum diperoleh informasi mengenai total antioksidantumbuhan suruhan pada keadaan segar dan kering, serta ketika dipanaskan dan tanpa dipanaskan. Informasi ini dibutuhkan karena dalam pemanfaatannya, tumbuhan suruhandapat dikonsumsi dalam keadaan segar sebagai lalapan, direbus, ataupun dikeringkan sebagai ramuan untuk mengobati asam urat (Dewani dan Sitanggang, 2009). Informasi total antioksidan dalam bahan makanan sangat dibutuhkan guna pengambilan keputusan dalam upaya memenuhi kebutuhan antioksidan tubuh sehubungan dengan pencegahan dan pengobatan penyakit.
Penelitian ini bertujuan mengukur total antioksidan tumbuhan suruhan (Peperomia pellucida [L.] Kunth) pada keadaan segar dan kering, serta dengan dan tanpa dipanaskan. Hasil penelitian ini diharapkan dapat memberikan informasi ilmiah mengenai total antioksidan dari tumbuhan suruhan dalam keadaan segar dan kering, serta pengaruh pemanasan terhadap kandungan total antioksidannya.

\section{METODOLOGI PENELITIAN}

Penelitian inidilaksanakan di Laboratorium Biokimia Jurusan Kimia Fakultas Matematika dan Ilmu Pengetahuan Alam Universitas Sam Ratulangi.Alat yang digunakan berupaspektrofotometer UV-Vis, sentrifusa, lemari pendingin,hotplate, oven,blender, desikator, kertas saring, labuerlenmeyer, labu takar, pipet mikro, pipet tetes,corong,gelas kimia, gelas arloji, timbangan digital, cawan porselin, batang pengaduk dan sudip.Bahan yang digunakan adalah tumbuhan suruhan (Peperomia pellucida[L.] Kunth), $\quad \mathrm{CH}_{3} \mathrm{COOH}, \quad$ air demineralisasi, $\mathrm{HCl}$,

$\mathrm{CH}_{3} \mathrm{OH}, \mathrm{CH}_{3} \mathrm{COONa} .3 \mathrm{H}_{2} \mathrm{O}$, 2,4,6-tri-pyridyls-triazine (TPTZ), $\mathrm{FeCl}_{3} \cdot 6 \mathrm{H}_{2} \mathrm{O}, \mathrm{FeSO}_{4} \cdot 7 \mathrm{H}_{2} \mathrm{O}$, vaselin dan akuades.

\section{Pengambilan dan Preparasi Sampel}

Sampel tumbuhan suruhan (Peperomia pellucida [L.]Kunth) diambil dari lingkungan sekitar kampus UNSRAT. Sampel tersebut dibagi dalam dua perlakuan, yakni segar dan kering (dikeringanginkan selama 1 bulan di tempat yang tidak langsung terkena cahaya matahari). Sampel kering dan segar diukur kadar airnya menggunakan metode gravimetri (Sudarmadji et al., 1989). Sampel segar dan kering masingmasing dibagi lagi dalam dua perlakuan, yakni dengan pemanasan dan tanpa pemanasan. Pada proses tanpa pemanasan, sampel ditimbang sebanyak 10 gram lalu ditambahkan air demineralisasi sebanyak $100 \mathrm{~mL}$ lalu diblender. Pada proses pemanasan, 10 gram sampel ditambahkan $100 \mathrm{~mL}$ air demineralisasi kemudian dipanaskan selama 15 menit pada suhu $100^{\circ} \mathrm{C}$, lalu didinginkan dalam desikator, diblender dan disaring. Sari yang diperolehdiambil sebanyak $1 \mathrm{~mL}$ dan 
ditambahkan $9 \mathrm{~mL}$ metanol, dicampur dan dimaserasi selama 12 jam pada suhu $4^{\circ} \mathrm{C}$ (dalam lemari pendingin), lalu disentrifugasi pada kecepatan 5000 rpm selama 30 menit. Supernatan yang terbentuk digunakan untuk pengukuran total antioksidan menggunakan metode Ferric Reducing Antioxidant Power(FRAP). Setiap sampel diulangi sebanyak 3 kali.

\section{Penentuan Kadar Air (Sudarmadji et al., 1989)}

Sampel ditimbang sebanyak \pm 3 gram di dalam cawan porselin, dimasukkan dalam oven dengan temperatur $105^{\circ} \mathrm{C}$ selama 3 jam kemudian didinginkan dalam desikator selama 30 menit, lalu sampelditimbang.Kemudian dipanaskan kembali dalam oven dan didinginkan lagi sampai mencapai berat konstan. Perhitungan kadar air:

$$
\text { Kadar Air }=\frac{A-B}{A} \times 100 \%
$$

Keterangan:

$\mathrm{A}=$ Berat sampel sebelum dipanaskan

$\mathrm{B}=$ Berat sampel setelah dipanaskan

\section{Pegujian Aktivitas Antioksidan (Szöllösi dan Varga, 2002)}

Pengujian aktivitas antioksidan sampel dilakukan dengan mengukur total konsentrasi antioksidan dalam tumbuhan suruhan menggunanakan metode FRAP yangdidasarkan pada reaksi reduksi $\mathrm{Fe}^{3+}$ menjadi $\mathrm{Fe}^{2+}$ oleh senyawa antioksidan (Benzie dan Strain, 1996). Metode FRAP meliputi tahap pembuatan reagen FRAP, pembuatan larutan standar, penentuan panjang gelombang maksimum dan pengukuran total antioksidan dalam sampel menggunakan spektrofotometer. Total antioksidan ditentukan dengan menggunakan kurva stadar konsentrasi $\mathrm{Fe}^{2+}$.

\section{HASIL DAN PEMBAHASAN}

\section{Total Antioksidan}

Total antioksidan tumbuhan suruhandiukur menggunakan metode FRAP, yang prinsipnya adalah mengukur konsentrasi kompleks $\mathrm{Fe}^{2+}$-TPTZ hasil reduksi $\mathrm{Fe}^{3+}$ TPTZ oleh senyawa antioksidan. Kekuatan antioksidan suatu senyawa dianalogikan dengan kemampuan mereduksi ion $\mathrm{Fe}^{3+}$ menjadi $\mathrm{Fe}^{2+}$ (Halvorsen et al., 2002). Apaket al. (2007) mengemukakan reaksi reduksi yang mungkin terjadi bila antioksidan tersebut berupa senyawa fenol (ArOH), sebagai berikut:

$$
\begin{gathered}
\mathrm{Fe}^{3+}-(\mathrm{TPTZ})_{2}+\mathrm{ArOH} \rightarrow \mathrm{Fe}^{2+}-(\mathrm{TPTZ})_{2}+ \\
\mathrm{ArO} \bullet+\mathrm{H}^{+} \\
\text {Kompleks Fe }{ }^{2+}-\mathrm{TPTZ} \text { berwarna biru. }
\end{gathered}
$$

Hasil scannin $g$ panjang gelombang spektrofotometer untuk penentuan kandungan total antioksidan tumbuhan suruhan (Peperomia pellucida [L.] Kunth) diperoleh absorbansi maksimum pada panjang gelombang $593 \mathrm{~nm}$. Panjang gelombang ini sejalan dengan yang dilaporkan oleh beberapapeneliti sebelumnya (Benzie dan Strain, 1996; Szöllösi dan Varga, 2002; Halvorsen et al., 2002; Dragland et al., 2003; Then et al., 2003).

\section{Total Antioksidan Tumbuhan Suruhan}

Total antioksidan tumbuhan suruhan segar dan kering disajikan dalam Gambar 1. Ekstrak tumbuhan suruhan kering memiliki kandungan total antioksidan yang secara nyata lebih tinggi daripada ekstrak suruhan segar $(p<0,05)$. Tingginya total antioksidan pada ekstrak suruhan kering ini mendukung hasil penelitian yang dilakukan oleh Lasama (2008) yang melakukan penelitian terhadap beberapa jenis benalu, dan menemukan bahwa kandungan total antioksidan benalu kering 3-5 kali lebih besar daripada benalu segar.

Faktor penyebab tingginya total antioksidan dalam ekstrak suruhan kering adalah kadar airnya yang sedikit. Banyaknya air yang terkandung dalam suruhan akan berpengaruh terhadap faktor pengenceran senyawa antioksidan dalam suruhan tersebut. Semakin rendah kadar air yang terkandung dalam tumbuhan suruhan, maka semakin tinggi pula total antioksidan yang akan terukur.Perbandingan kandungan kadar air dalam tumbuhan suruhan disajikan pada Tabel 1.Tingginya kadar air tumbuhan suruhan segar disebabkan juga oleh lingkungan tumbuhnya yang agak lembab atau sedikit terlindung (Dalimartha, 2006).

Tabel 1. Kandungan Kadar Air pada Tumbuhan Suruhan

\begin{tabular}{|c|c|}
\hline Sampel & Kadar Air (\%) \\
\hline Suruhan Segar & 94,45 \\
\hline Suruhan Kering & 11,56 \\
\hline
\end{tabular}




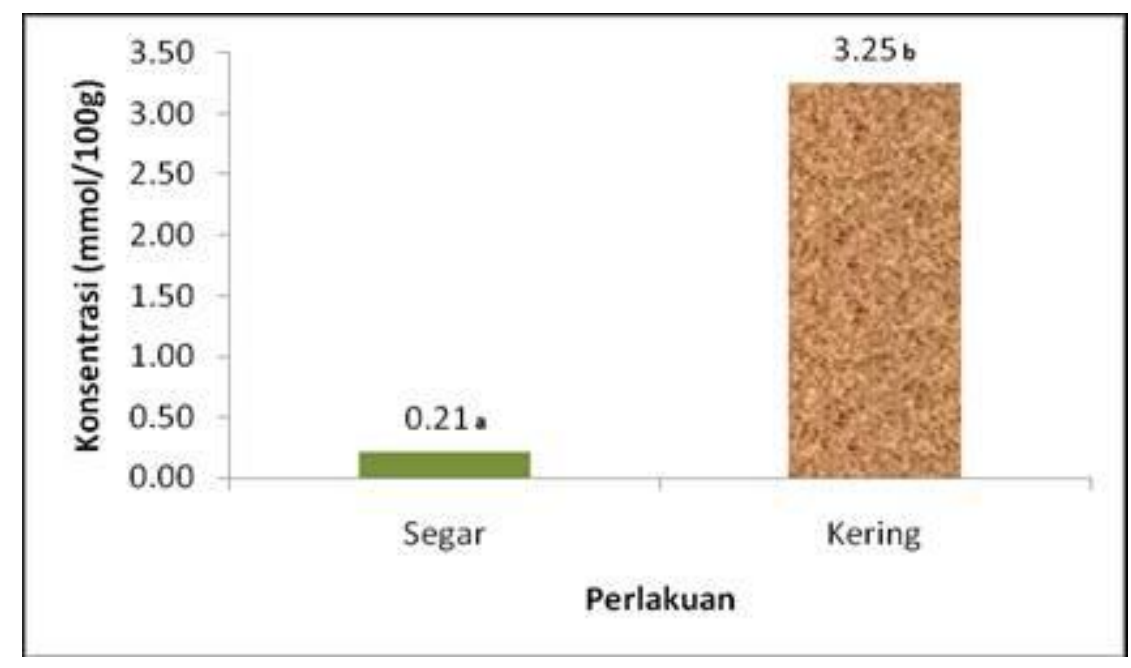

Ket : Huruf berbeda di belakang angka menunjukkan berbeda nyata pada $\alpha=0,05$

Gambar 1.Diagram Total Antioksidan Ekstrak Tumbuhan Suruhan Segar dan Kering

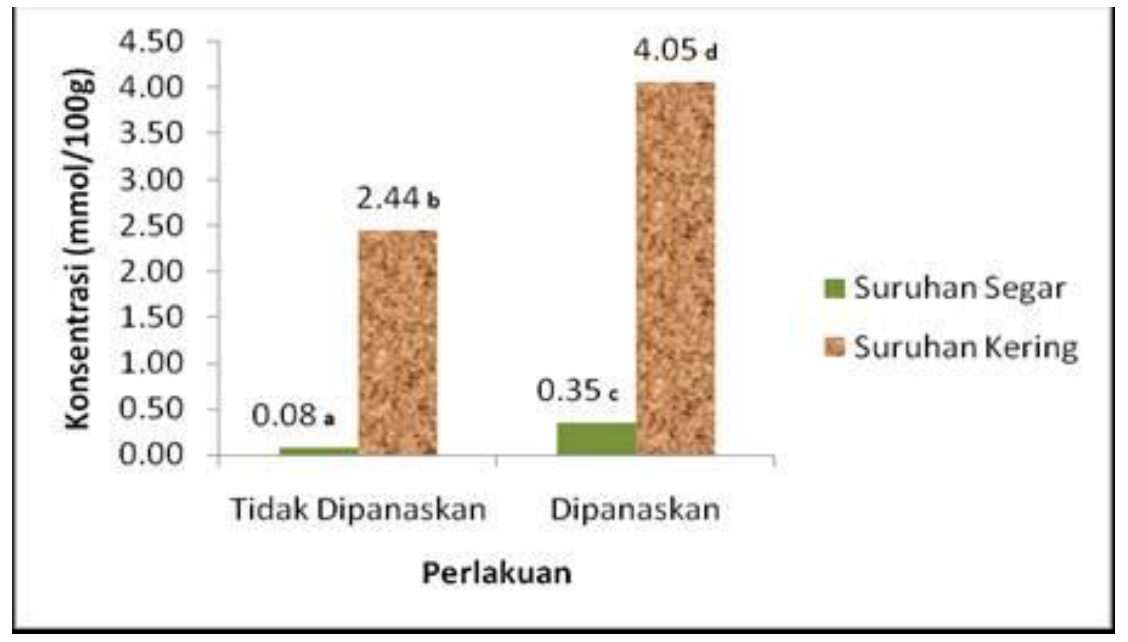

Gambar 2. Diagram Total Antioksidan Ekstrak Suruhan Kering dan Segar yang Dipanaskan maupun tidak Dipanaskan

\section{Pengaruh Pemanasan terhadap Total Antioksidan pada Tumbuhan Suruhan}

Kandungan total antioksidan pada tumbuhan suruhan segar dan kering yang masing-masing diberi perlakuan pemanasan dan tanpa pemanasan disajikan dalam Gambar 2. Ekstrak suruhan segar dan kering yang dipanaskan memiliki total antioksidan lebih tinggi daripada yang tidak dipanaskan.

Total antioksidan ekstrak suruhan segar yang dipanaskan lebih tinggi daripada ekstrak suruhan segar yang tidak dipanaskan. Hal yang sama juga terjadi pada ekstrak suruhan kering. Hasil uji beda nyata terkecil (BNT) menunjukkan terdapat perbedaan yang signifikan pada setiap perlakuan $(\mathrm{p}<0,05)$. Tingginya total antioksidan pada ekstrak suruhan yang dipanaskan ini mendukung hasil penelitian yang dilakukan oleh Momuat et al. (2010), yang meneliti tentang total antioksidan pada beberapa jenis sayuran, dan menemukan bahwa kandungan total antioksidan pada semua sayur yang dipanaskan dua kali lebih tinggi daripada sayur yang tidak dipanaskan. 
Tingginya total antioksidan pada ekstrak suruhan yang dipanaskan disebabkan oleh proses pemanasan yang membuat dinding sel tanaman menjadi rusak, sehingga senyawa-senyawa dalam sel, termasuk senyawa antioksidan, dapat ke luar sel dan masuk ke dalam pelarut air. Selain itu, pemanasan juga diduga menyebabkan pemutusan ikatan kimia dari makromolekul menghasilkan molekul-molekul yang relatif lebih kecil berat molekulnya.Molekulmolekul kecil tersebut, termasuk senyawa antioksidan, relatif lebih mudah larut dalam air daripada makromolekulnya. Afriansyah (2006) yang meneliti kandungan antioksidan pada wortel melaporkan bahwa proses pemanasan ternyata meningkatkan kadar antioksidan pada wortel kira-kira sepertiga kali lebih banyak daripada yang tidak dipanaskan dan proses pemanasan akan melarutkan sebagian dinding selulosa yang tebal, dan membebaskan nutrisi dengan cara memecah membran sel, sehingga khasiat antioksidannya turut meningkat. Semua hal tersebut menjadi alasan tingginya kandungan total antioksidan pada ekstrak suruhan yang dipanaskan dibandingkan dengan yang tidak dipanaskan.

Senyawa-senyawa antioksidan pada tumbuhan suruhan dalam penelitian ini berperan dalam mereduksi ion $\mathrm{Fe}^{3+}$ menjadi ion $\mathrm{Fe}^{2+}$.Senyawa pereduksi atau reduktor yang terdapat dalam tumbuhan suruhan digolongkan sebagai antioksidan alami.Senyawa antioksidan alami yang terdapat dalam tumbuhan suruhan di antaranya adalah alkaloid, tanin, saponin dan senyawa polifenol (Dalimartha, 2006). Wei et al. (2011) melaporkan bahwa tumbuhan suruhan mengandung senyawa phytol (37.88\%), 2-naphthalenol, decahydro(26.20\%), hexadecanoic acid, methyl ester (18.31\%) dan 9,12-octadecadienoicacid (Z,Z)-, methyl ester (17.61\%). Antioksidan alami pada umumnya dapat menghambat proses terbentuknya malondialdehida (MDA) yang terjadi dalam plasma darah. Rendahnya kadar MDA dalam plasma darah akan mengurangi terjadinya kerusakan oksidatif pada jaringan tubuh (Winarsi, 2007). Dengan demikian, banyaknya kandungan antioksidan alami yang terdapat pada tumbuhan suruhan, membuat tumbuhan ini memiliki khasiat sebagai obat yang digunakan secara tradisional untuk menurunkan kolesterol darah, yang dapat memicu terjadinya penyakit jantung koroner.

\section{KESIMPULAN DAN SARAN}

\section{Kesimpulan}

Penelitian ini menyimpulkan bahwa :

1. Ekstrak suruhan kering memiliki kandungan total antioksidan yang lebih tinggi daripada ekstrak suruhan segar, dengan konsentrasi ekstrak suruhan kering 3,25 mmol/100g dan ekstrak suruhan segar dengan konsentrasi 0,21 $\mathrm{mmol} / 100 \mathrm{~g}$.

2. Pemanasan selama 15 menit pada suhu $100^{\circ} \mathrm{C}$ meningkatkan kandungan total antioksidan pada ekstrak suruhan, dengan rata-rata konsentrasi total antioksidan tertinggi secara berturut-turut adalah ekstrak suruhan kering dengan pemanasan $(4,05 \mathrm{mmol} / 100 \mathrm{~g})$, ekstrak suruhan kering tanpa pemanasan $(2,44$ mmol/100g), ekstrak suruhan segar dengan pemanasan $(0,35 \mathrm{mmol} / 100 \mathrm{~g})$ dan ekstrak suruhan segar tanpa pemanasan $(0,08 \mathrm{mmol} / 100 \mathrm{~g})$.

\section{Saran}

Perlu dilakukan penelitian lebih lanjut untuk mengukur tingkat oksidasi dalam plasma darah hewan coba yang mengkonsumsi tumbuhan suruhan.

\section{DAFTAR PUSTAKA}

Afriansyah, N. 2006. Wortel: Antioksidan, penurun kolesterol dan resiko stroke. Info Kesehatan. http:// www.kompas.com/kesehatan/news/0 $\underline{\text { 207/08/011205. htm. [5 April 2011] }}$

Apak, R., G. Kubilay, D. Birsen, O. Mustafa, E.C. Saliha, B. Burcu, B. Isil, O. Dilek. 2007. Comparative Evaluation of Various Total Antioxidant Capacity Assays Applied to Phenolic Compounds with The Cuprac Assay. Molecules 12:1496-1547.

Benzie, F.F.I., dan J.J. Strain. 1996. The Ferric Reducing Ability of Plasma as a Measure of "Antioxidant Power": The FRAP Assay.Analytical Biochemistry 239: 70-76 
Dalimartha, S.2006. Atlas Tumbuhan Obat Indonesia Jilid 4.Puspaswara, Jakarta.

Dalimartha, S.dan M. Soedibyo.1999. Awet Muda dengan Tumbuhan Obat dan Diet Suplemen. Trubus Agriwidya, Jakarta.

Dewani dan M. Sitanggang. 2006. 33 Ramuan Penakluk Asam Urat. Agro Media Pustaka, Jakarta.

Dragland, S., H. Senoo, K. Wake, K. Holte, $\&$ R. Blomhoff. 2003. Several Culinary and Medicinal Herbs are Important Sources of Dietary Antioxidants. Journal of Nutrition 133: 1286-1290.

Halvorsen, B. L., K. Holte., M. C. W. Myhrstad., I. Barikmo., E. Hvattum., S. F. Reberg., A. B. Wold., K. Haffner., H. Baugerod., L. F. Andersen., O. Moskaug., D. R. Jacobs., J. dan R. Blomhoff. 2002. A Systematic Screening of Total Antioxidant In Dietary Plants.J. Nutrition. 132 : 461471.

Hariana, H.A. 2006. Tumbuhan Obat dan Khasiatnya, seri 3 Agrisehat. Penebar Swadaya, Jakarta.

Kumalaningsih, S. 2006. Antioksidan Alami: Penangkal Radikal Bebas. Trubus Agrisarana, Jakarta.

Lasama, S. N. 2008. Total Antioksidan Dalam Beberapa Jenis Benalu [skripsi]. FMIPA UNSRAT, Manado.

Momuat, L.I., F. Fatimah, O. Mamondol, \& F. Wehantouw. 2010. Efek Pemanasan terhadap Total Antioksidan dari Beberapa Jenis Sayuran Tinutuan. Chemistry Progress 3(2):85-90.

Steinberg, D. 1997. Oxidative modification of LDL and atherogenesis. Circulation 95:1062-1071.

Subroto, A. 2006.Ramuan Herbal untuk Diabetes Melitus. Penebar Swadaya, Jakarta.

Sudarmadji, S., B. Haryono, \& Suhardi.1989. Prosedur Analisis Untuk Bahan Makanan dan Pertanian. Liberty, Yogyakarta.
Szöllözi, R. dan I. Varga. 2002. Total Antioxidant Power in some Species of Labiate (Adaptation of FRAP Method). J. Biologica Szegediensis 46: 125-127.

Tarigan, I.M. br, S. Bahri dan A. Saragih. 2012. Aktivitas Antihiperurisemia Ekstrak Etanol Herba Suruhan (Peperomia pellucida (L.) Kunth) Pada Mencit Jantan. Journal of Pharmaceutics and Pharmacology 1(1):37-43.

Then, M., Szentmihalyi, K.,SarkÖzi, A.,Varga, I.S. 2003. Examination on Antioxidant Activity in The Greater Celandine (Chelidonium majus L.) Extract by FRAP Method. $J$. Biologica Szegediensis47:115-117.

Winarsi, H.2007. Antioksidan Alami dan Radikal Bebas, Potensi dan Aplikasinya Terhadap Kesehatan. Kanisius, Yogyakarta.

Wei, L.S., W. Wee, J.Y.F. Siong, \& D.F. Syamsumir. 2011. Characterization of Anticancer, Antimicrobial, Antioxidant Properties andChemical Compositions of Peperomia pellucida Leaf Extract. Acta Medica Iranica 49(10): 670-674. 